\title{
O KSZTAŁCENIU STUDENTÓW NIEPEŁNOSPRAWNYCH W UNIWERSYTECIE
}

\author{
About teaching disabled students at the university
}

Su m mary: 1 . The goal of this article is to present the situation of disabled persons at the university in the 21st century on the basis of selected examples. 2. Methodology. The author used the historiographical method for the analysis of document and observation. 3. The main results of analysis. The author presents the following issues: disabled persons and the university (masters context), The University Office for Disabled Persons, educational and professional activities of disabled persons, and two models of disabilities (medical and interactive). The author also shows the problem of disability in the context of such categories as: society, state, culture, and civilization. The author discusses the formation of altruistic attitudes towards disabled persons and educational assistance for them at the university when they are studying. The article examines issues surrounding hearing-impaired persons at the university (methods of working with such students) and the blind within the context of visual culture at the university. The author presents some problems of conscience and disabled persons at the university. 4. Limitations of results of analysis. This article is a contribution to discussions of the place of disabled persons at the university. Limitations concern relations to the university. 5. Practical implications. The results of the analysis may be used in these discussions as an argument for the change of situation of disabled at the university. 6. Social implications. The results of analysis may be related to the group of disabled students at the university. 7. The originality of the article (new value, novelty). The paper is based on original sources and on situations of disabled students at the university in the context of culture and possibilities of help.

Keywords: university, disabled, conscience, deaf and dumb persons, personalism, human rights, Christianity, ethics, master-follower, models, altruism, culture, civilization

\section{Wstęp}

Celem artykułu jest przedstawienie uwag o miejscu studentów niepełnosprawnych w szkole wyższej w kontekście humanistycznym, między innymi wświetle problematyki sumienia. Artykuł jest przyczynkarski, bo nie wyczerpuje tematyki, ale 
ma charakter przeglądu zagadnień, wnosząc także pewne oryginalne ujęcie tej problematyki.

Jak dotąd istnieje bardzo bogata bibliografia na temat poszczególnych typów niepełnosprawności (wiele tysięcy publikacji) oraz literatura przedmiotu dotycząca aplikacji pedagogiki specjalnej do pedagogiki szkoły wyższej ( $\mathrm{z}$ powodu ograniczonych ram artykułu kwestia ta będzie pominięta). Spróbuję spojrzeć na wybrane elementy istnienia niepełnosprawności w ramach uniwersytetu w kontekstach (aspektach) kulturowych, bliskich realistycznym ujęciom pedagogiki kultury. Proponuję tu posługiwanie się kilkoma nowymi pojęciami w odniesieniu do dyscypliny naukowej, aplikowanej do problematyki szkoły wyższej: 1) tyflopedagogika szkoły wyższej ( $\mathrm{w}$ odniesieniu do pedagogiki szkoły wyższej stosowanej do osób niewidomych, ociemniałych, niedowidzących), 2) surdopedagogika szkoły wyższej ( $w$ odniesieniu do pedagogiki szkoły wyższej aplikowanej do osób głuchych, ogłuchłych, niedosłyszących), 3) psychopedagogika szkoły wyższej (w odniesieniu do pedagogiki szkoły wyższej aplikowanej do osób chorych psychicznie), 4) oligofrenopedagogika szkoły wyższej (w odniesieniu do pedagogiki szkoły wyższej aplikowanej do osób niepełnosprawnych intelektualnie), 5) kinezjopedagogika (lub kinetopedagogika) szkoły wyższej ( $w$ odniesieniu do pedagogiki szkoły wyższej stosowanej do osób z niepełnosprawnościami narządów ruchu).

\section{Niepełnosprawni a uniwersytet (kontekst mistrza)}

Problematyka osób niepełnosprawnych w szkołach wyższych jest zagadnieniem odrębnym, różniącym się nieco od kwestii uczenia w szkołach niższych typów ${ }^{1} \mathrm{z}$ uwagi na wymogi większej samodzielności stawiane osobom studiującym.

Pełnosprawni studenci (o ile o takowej kategorii można mówić) w celu zdobycia wykształcenia wyższego, odpowiedniej wiedzy merytorycznej i doświadczeń zawodowych, oczywiście uczęszczają na wykłady, konwersatoria, ćwiczenia, warsztaty, seminaria, piszą prace, przeprowadzają doświadczenia w laboratoriach, odbywają programowe praktyki studenckie, chodzą do bibliotek, czytają, notują, uczą się ze wskazanych materiałów, przygotowują się z podanego zakresu wiedzy, zdobywają zaliczenia, zdają egzaminy, zaliczają programowo przewidziane zajęcia na kolejnych latach studiów, sporządzają pracę dyplomową, bronią jej przed określoną komisją, a po spełnieniu wszystkich warunków - otrzymują tytuł zawodowy w określonej specjalności jako absolwenci studiów pierwszego lub drugiego stopnia (licencjat, magisterium lub odpowiednio zawodowe tytuły równorzędne: inżyniera). Podobną kwestią jest sprawa studiów doktoranckich (trzeciego stopnia).

\footnotetext{
${ }^{1}$ Por. np. Maria Grzegorzewska, Psychologja niewidomych, t. 1 (Warszawa, Lwów: Naukowe Towarzystwo Pedagogiczne 1929); Edukacja osób niepetnosprawnych, red. Aleksander Hulek (Warszawa: Polska Fundacja Upowszechnienia Nauki 1993); Franciszek Wojciechowski, Dziecko niepetnosprawne wśrodowisku wiejskim, (Rzeszów: WSP 1993); Hanna Żuraw, Uczestnictwo kulturalne młodzieży niepetnosprawnej (Warszawa: Wydawnictwo „Żak” 1996).
} 
Teoretycznie, wszystkie stopnie studiów wyższych są w Polsce potencjalnie dostępne także dla osób niepełnosprawnych, a przynajmniej dla pewnej ich grupy, zdolnej do spełnienia warunków przewidzianych prawem.

Nieco inaczej niż studia osób pełnosprawnych, wygląda sprawa studiów osób niepełnosprawnych w praktyce. Chcąc zdobyć wiedzę w określonej dziedzinie oraz posiadać dany tytuł zawodowy (lub stopień naukowy), uprawniający do wykonywania konkretnego zawodu, muszą w proces uczenia się włożyć o wiele więcej wysiłku, poświęcić o wiele więcej czasu, pokonać o wiele więcej trudności, przeszkód, barier, także mentalnych ${ }^{2}$, niż ich pełnosprawni koledzy i koleżanki studiujący ten sam kierunek.

Kwestię uczestnictwa osób niepełnosprawnych wedukacji na poziomie studiów wyższych należy traktować podobnie jak traktuje się edukację uczniów niepełnosprawnych oraz ich uczestnictwo w kulturze (na miarę ich możliwości)3. Student niepełnosprawny jest w pełni osobą, w pełni człowiekiem, mimo posiadanych deficytów (braków funkcjonalnych o zróżnicowanej etiologii). Personalistyczno-aksjologiczne ujęcie problematyki ludzi niepełnosprawnych dotyczy także studentów nie w pełni sprawnych. Wymaga to przede wszystkim tak zwanego „ludzkiego”, osobowego, indywidualnego podejścia do ich specyficznych problemów, a nie tylko schematycznej, administracyjnej realizacji prawa osób niepełnosprawnych do studiów wyższych.

Prawdziwy humanizm w podejściu do osób niepełnosprawnych zaczyna się od dostrzeżenia ich pełnoprawnego (pełnego, czyli jak najbardziej pełnosprawnego) człowieczeństwa, które w istocie niczym nie różni się od człowieczeństwa osób sprawnych w pełni. Człowieczeństwo, bycie osobą samo z siebie jest jednakowe dla wszystkich ludzi. Każdy człowiek od poczęcia do śmierci posiada niezbywalną godność, z natury, ze swej istoty. Godność ludzka wynika z prawa naturalnego, czyli prawa przyrodzonego człowiekowi zawsze i wszędzie, niezależnie od jakiejkolwiek umowy społecznej i jakiegokolwiek prawa stanowionego.

Na studiach liczy się nie tylko kształcenie, ale też wychowanie studentów. Chodzi o to, aby prowadzić człowieka (studenta) od stanu gorszego do stanu lepszego, a nie na odwrót. Jako pewna oczywistość jest to przyjęte w pedagogice kultury czy w pedagogice klasycznej. Ponieważ u podstaw wychowania stoi zawsze owa starogrecka paidea, wedle której kultura jest wychowaniem, a wychowanie zarazem kulturą, przeto należy sprawy kultury i wychowania rozpatrywać łącznie. Ponadto ponieważ wychowanie opiera się na transcendentaliach (bycie, jedni, dobru,

\footnotetext{
${ }^{2}$ Por. np. Agata Migas, „Problemy psychospołeczne osób z ograniczoną sprawnością”. Niepetnosprawność i Rehabilitacja 4 (2008): 22-42; Remigiusz Kijak, „Stygmatyzacja społeczna czy akceptacja? Wyniki badań”. Niepetnosprawność i Rehabilitacja 1 (2007): 3-24; Teresa Cwalina, „Dotykanie niewidzialnego. Z doświadczeń tyflologa warteterapii”, w: Edukacja warteterapii: Międzynarodowa Konferencja Szkoleniowo-Naukowa z cyklu „Psychiatria i Sztuka”, red. Grażyna Borowik, Andrzej Kowal (Kraków: Wydz. Sztuki Uniwersytetu Pedagogicznego im. KEN, Fundacja Instytut Wydawniczy „MAXIMUM” 2013): 41-49.

${ }^{3}$ Mariusz M. Tytko, „Kilka uwag o udziale ucznia niepełnosprawnego w kulturze”. Niepełnosprawność i Rehabilitacja 4 (2008), 67-72.
} 
prawdzie, pięknie), przeto należy rozpatrywać je zawsze realistycznie (realizm) w odniesieniu do rzeczywistego bytu (grec. to on), zawsze do jedni (grec. to hen, tu: do jedności, jedni osoby ludzkiej jako osobnej całości nierozerwalnej), nadto do dobra (grec. agaton), prawdy (grec. aletheia) i piękna (grec. kalon). Byt jest zarazem jednią, prawdą, dobrem i pięknem - to są najważniejsze transcendentalia ${ }^{4}$. Wychowanie zatem ulepsza człowieka wewnętrznie (aspekt dobra), „uprawdziwia” go (aspekt prawdy), upięknia (aspekt piękna), spaja jego jedność osobową i powoduje, iż jest bardziej spójny wewnętrznie (aspekt jedni), czyni go intensywniej istniejącym, bytującym po ludzku (aspekt bytu). Proces prawidłowego wychowania sprawia, że ludzi stają się lepsi, prawdziwsi, piękniejsi, realniejsi i spójniejsi z samymi sobą (w jedni własnej osoby ludzkiej).

$\mathrm{W}$ pedagogice, po pierwsze, chodzi o stawanie się coraz to lepszym człowiekiem oraz, po drugie, o pozytywne, czynne oddziaływanie na innych dobrem, prawdą, pięknem, wszelkimi wartościami, ucieleśnionymi w konkretnej postaci, kształcie, sytuacjach, aby także inni stawali się coraz lepszymi ludźmi. Nasza epoka nie potrzebuje tylko nauczycieli, ale świadków, jak mówił św. Jan Paweł II, dlatego każdy pedagog musi wpierw ulepszyć samego siebie (być świadkiem dobra oraz świadczyć swoim życiem o dobru), aby następnie mógł wiarygodnie próbować ulepszać innych wychowawczo, w myśl zasady: Medice, cura te ipsum. Nadto każdy pedagog musi wpierw upięknić wewnętrznie samego siebie, aby następnie mógł wiarygodnie próbować upiękniać innych duchowo, moralnie (świadczyć o pięknie i być świadkiem piękna). Podobnie rzecz się ma z prawdą. Każdy pedagog musi wpierw uczynić samego siebie bardziej prawdziwym (świadkiem prawdy oraz świadczyć o prawdzie), aby następnie mógł wiarygodnie próbować czynić prawdziwszymi, autentyczniejszymi innych ludzi. Nadto każdy pedagog musi wpierw samemu „bardziej być”, niż „więcej mieć” (jak nauczał św. Jan Paweł II), aby następnie mógł dopiero wiarygodnie próbować wzmacniać innych duchowo, moralnie (świadczyć o bycie ludzkim sobą samym, a także być świadkiem bytowości ludzkiej i wzorcem człowieka).

Idąc dalej tropem transcendentaliów, trzeba powiedzieć, że każdy pedagog musi wpierw samemu stać się jednością wewnętrzną (być spójnym z samym sobą), aby następnie mógł dopiero wiarygodnie próbować wzmacniać jedność (wewnętrzną spójność duchową, moralną) innych, to jest świadczyć o jedności osoby ludzkiej, być wzorcem człowieka spójnego w sobie samym, jednolitego, niepodzielnego, wewnętrznie niesprzecznego z samym sobą). Nie chodzi tu więc tylko o mówienie studentom o dobru, prawdzie i pięknie, o wartościach (uczenie czysto werbalne jest całkowicie nieskuteczne) czy o prawidłowym zachowaniu się wobec ludzi niepełnosprawnych, lecz o realne czynienie tego, co dobre, prawdziwe i piękne. Tylko konkretne, wartościowe działania wobec indywidualnych osób ma sens. Te czyny

4 Pomijam tu „rzecz” jako trancendentale - jako że wpedagogice kwestia dotyczy człowieka. Wychowujemy wszak człowieka (osobę ludzką), a nie rzecz (przedmiot). Przedmioty (rzeczy) mogą być, co prawda, użyte jako środki dydaktyczne w procesie wychowania osób, ale to jest inne zagadnienie. 
pociągają, zachwycają, chce się je naśladować jako doskonałe, słuszne, pożyteczne, potrzebne.

Nauczyciel na rzecz osób niepełnosprawnych działa skuteczniej swoimi czynami, niż werbalizmem ex cathedra. Mistrz wobec ucznia działa przykładem własnym, świadectwem czynu, a nie tylko słowem, a nawet bardziej czynem, niż słowem, stąd tak ważna jest wzorczość w wychowaniu, także na poziomie szkoły wyższej w relacjach z osobami niepełnosprawnymi oraz w sytuacjach ich dotyczących. Wzór jest lub może być naśladowany przez innych, skoro Verba docent, exempla trahunt, szczególnie w relacjach interpersonalnych, wymagających dyskrecji, taktu, empatii, delikatności, subtelności, domyślności, życzliwości, przyjazności, serdeczności, wyrozumiałości, łagodności, spokoju, ciepła, wyczucia sytuacji i tworzenia atmosfery bezpieczeństwa.

Każdy nauczyciel akademicki powinien zdawać sobie z tego sprawę, że swoim określonym, wielokrotnie powtarzalnym, stałym, ciągłym, zawsze życzliwym, zawsze przyjaznym postępowaniem wobec studentów - osób niepełnosprawnych, daje wzór do naśladowania studentom pełnosprawnym, jak oni mają traktować swoich nie w pełni sprawnych kolegów czy koleżanki. Działa on także szerzej na całą społeczność lokalną, bo transmisja utrwalonych wartości kulturowych przenosi się dalej, pozostaje w pamięci tych, którzy jego zachowanie widzieli, słyszeli jego słowa w konkretnej sytuacji. Wszak ci studenci, których on tu-i-teraz uczy i którym daje konkretny przykład własną osobą, własnym czynem, być może staną się kiedyś nauczycielami, menadżerami, politykami, naukowcami, lekarzami i będą mieli w swojej pamięci ów wielokrotnie powtarzany, pozytywny wzorzec postępowania wobec osób niepełnosprawnych, utrwalony w postaci długoterminowej pamięci obrazowej. Po latach słowa wykładu ulecą, a obrazy konkretnych, dobrych czynów (działania w konkretnej sytuacji) pozostają i to one mają większą moc wychowawczą. $\mathrm{W}$ ten sposób pozytywne wzorce postępowania wobec osób niepełnosprawnych, wyuczone poprzez naśladowanie działań podczas studiów wyższych w sposób dowolny lub mimowolny, zostaną przeniesione dalej, poza uczelnię, do całej społeczności.

Stąd tak wielką wagę przywiązuje się do nauczenia nauczycieli akademickich, aby w swojej praktyce nabyli pewne wiadomości o potrzebach osób niepełnosprawnych. I nie tylko nabyli, ale także, aby stosowali je w praktyce w swojej pracy na uczelni i w życiu, wszędzie tam, gdzie to jest potrzebne.

\section{Uczelniane Biuro do spraw Osób Niepełnosprawnych}

Niektóre uczelnie, jak na przykład Uniwersytet Jagielloński, Uniwersytet Warszawski, Uniwersytet Pedagogiczny im. KEN w Krakowie, powołały komórki organizacyjne, które mają służyć niepełnosprawnym studentom (szerzej: wszystkim osobom niepełnosprawnym w danej szkole wyższej oraz kandydatom na studia do tej uczelni). Biuro do spraw Osób Niepełnosprawnych (ang. The Student Disability Support Office) służy bezpośrednio nie tylko osobom niepełnosprawnym, ale także 
pośrednio działa na ich rzecz, ucząc nauczycieli akademickich oraz inne osoby, jak należy postępować ze studentami niepełnosprawnymi5.

Uniwersytet Jagielloński, wychodząc naprzeciw osobom niepełnosprawnym, kieruje się następującymi priorytetami: 1) zasada równych praw i równych obowiązków (w porównaniu z prawami i obowiązkami osób pełnosprawnych), 2) możliwie jak największy dostęp osób niepełnosprawnych do głównego nurtu kształcenia, 3) wsparcie studentów-inwalidów poprzez nowoczesne serwisy (służby pomocnicze), które kompensują dane niepełnosprawności studentom. Dotyczy to głównie: [1] osób z wadami słuchu (niesłyszących, słabosłyszących, czyli niedosłyszących), [2] osób z wadami wzroku (niewidomych, słabowidzących, zatem niedowidzących), [3] osób z wadami dotyczącymi narządów ruchu (niepełnosprawnych ruchowo, mowa przede wszystkim o niedomaganiu nóg i kręgosłupa), [4] osób z chorobami psychicznymi (pozwalającymi jednak na podjęcie studiów). W Krakowie od dawna istniała Poradnia Zdrowia Psychicznego dla Studentów, ale tu mowa o czymś innym, niż standardowa psychoterapia: o konkretnej pomocy w studiowaniu dla osób z deficytami psychiki o różnej etiologii: organicznej czy nieorganicznej (wsparcie niezależnie od medycyny, także wsparcie przedmedyczne).

Jak informują oficjalne strony internetowe Biura ds. Osób Niepełnosprawnych $\mathrm{UJ}^{6}$, od 2005 roku na mocy decyzji rektorskiej istnieje jednostka, która zajmuje się pomocą studentom niepełnosprawnym, nadto zaś tworzy rozwiązania systemowe, umożliwiające lepszy dostęp do edukacji na poziomie szkoły wyższej. Biuro to: 1) zapewnia osobom niepełnosprawnym pełne uczestnictwo w zajęciach, 2) zapewnia osobom niepełnosprawnym bezpieczny dostęp do wszystkich budynków UJ, 3) tworzy warunki zdawania egzaminów w formie alternatywnej, 4) usuwa bariery informacyjne i świadomościowe (mentalne). Wspomniane działania należą do misji Biura, mając charakter długofalowy, longitudinalny, systemowy. Biuro reprezentuje interesy lub potrzeby osób niepełnosprawnych wobec władz uczelni, a także wobec wszystkich jednostek Uniwersytetu Jagiellońskiego. W uniwersytecie studiują osoby o różnym stopniu niepełnosprawności, nie zawsze ujawnianym, zwłaszcza w przypadkach lekkiego deficytu, stąd trudność w zewnętrznym jego rozpoznaniu w życiu codziennym przez inne osoby (inwalidztwo mało „widoczne”, stopnia „lekkiego”, jest dość często ukrywane w obawie przed odrzuceniem społecznym).

W rozbudowanej strukturze uniwersyteckiej i przy rozproszeniu studentów z deficytami, Biuro ds. Osób Niepełnosprawnych stało się niezbędne. Według oficjalnych informacji7, odbiorcami działań Biura są głównie niepełnosprawni

\footnotetext{
${ }^{5} \mathrm{~W}$ artykule wykorzystano m.in. upublicznione materiały pomocnicze Biura ds. Osób Niepełnosprawnych UJ [teksty rozdawane uczestnikom III Seminarium Dydaktyki Akademickiej, Kraków 26-27 listopada 2007 r. w Instytucie Pedagogiki UJ]; D. Nowak-Adamczyk, Rodzaje wsparcia i strategie nauczania studentów niestyszących istaboshyszących wkontekście kształcenia pedagogów, [materiał multimedialny prezentowany na powyższym Seminarium].

${ }^{6}$ Por. www.bon.uj.edu.pl [dostęp: 22.10.2008].

${ }^{7}$ Por. www.bon.uj.edu.pl [dostęp: 22.10.2008]. Tamże dział pt. Prowadzone działania.
} 
studenci UJ. Wiadomo jednak, że zgłaszają się tam także niepełnosprawni pracownicy UJ. Chodzi tu o następujące czynności Biura: a) współpraca z wydziałami (dziekanatami) w sprawach administracyjnych, które dotyczą studentów niepełnosprawnych, b) upraszczanie procedur i formalności związanych z niezbędną dokumentacją na temat studiów, c) pomoc w rozwiązywaniu problemów dotyczących zmiany trybu zaliczenia studiów, d) organizacja egzaminów w formie alternatywnej, e) organizacja grupy asystentów dla osób niepełnosprawnych, f) przystosowywanie kolejnych pomieszczeń dla osób niepełnosprawnych ruchowo, g) utworzenie w Bibliotece Jagiellońskiej stanowisk ze sprzętem umożliwiającym osobom niewidomym i niedowidzącym korzystanie $\mathrm{z}$ księgozbioru, $\mathrm{h}$ ) lobbowanie $\mathrm{u}$ władz na rzecz osób niepełnosprawnych w szkołach wyższych, i) współpraca z innymi, polskimi uczelniami kształcącymi osoby niepełnosprawne, j) współpraca międzynarodowa, k) wymiana doświadczeń, l) udział w konferencjach.

Obszary działań Biura według oficjalnych danych ${ }^{8}$ to: 1) integracja i aktywizacja społeczna, w tym 2) promocja zatrudnienia i aktywizacja zawodowa osób pozostających bez pracy i zagrożonych zwolnieniem z pracy, 3) nauka, kultura, edukacja i wychowanie, w tym sztuka, ochrona dóbr kultury i tradycji. Biuro działa także przy pomocy wolontariuszy. Liczba wolontariuszy zaangażowanych w działania na przykład w roku 2007/2008 wyniosła 10 osób. Biuro ds. Osób Niepełnosprawnych, według oficjalnych informacji, wśród form pomocy oferuje studentom UJ nie w pełni sprawnym: 1) pomoc informacyjno-poradniczą: a) pośrednictwo pracy, b) pomoc w dostępie do informacji o rynku pracy (o ofertach pracy, o instytucjach, inne informacje), c) działania na rzecz podnoszenia kwalifikacji, 2) pomoc w załatwianiu formalności, interwencje, 3) profesjonalną pomoc psychologiczną, 4) stypendia i nagrody, 5) szkolenia (zawodowe, przekwalifikowanie, doradztwo dotyczące zakładania własnego przedsiębiorstwa), 6) pośrednictwo pracy i kluby pracy, 7) edukację, 8) rozwój zainteresowań i uzdolnień, 9) pomoc lektorów, przewodników dla niewidomych, tłumaczy języka migowego dla głuchoniemych, 10) pomoc w znoszeniu barier architektonicznych, transportowych i komunikacyjnych dla osób niepełnosprawnych ruchowo.

Praca Biura nastawiona jest także na osoby przewlekle chore. $\mathrm{W}$ stosunku do nich, podobnie jak w przypadku osób niepełnosprawnych, wspomniane Biuro oferuje następujące działania: 1) pomoc informacyjno-poradniczą, 2) pomoc w załatwianiu formalności, interwencje, 3) profesjonalną pomoc psychologiczną, 4) stypendia i nagrody, 5) szkolenia zawodowe, przekwalifikowania i doradztwo dotyczące zakładania przedsiębiorstwa, 6) edukację, 7) rozwój zainteresowań i uzdolnień, 8) pomoc lektorów, przewodników i tłumaczy, 9) znoszenie barier architektonicznych, transportowych i komunikacyjnych9. Pracownicy Biura ds. Osób Niepełnosprawnych UJ opracowują materiały do podręczników akademickich, na przykład do podręcznika dla doktorantów przygotowanego przez wykładowców Wydziału Chemii UJ. Ukazano

\footnotetext{
${ }^{8}$ Por. www.bon.uj.edu.pl [dostęp: 22.10.2008].

${ }^{9}$ Por. www.bon.uj.edu.pl [dostęp: 22.10.2008] oraz por. także http://bazy.ngo.pl/search/info.asp?id=76535 [dostęp: 22.10.2008].
} 
w nim podstawowe zasady pracy ze studentem niepełnosprawnym oraz materiały wypracowane w ramach projektów, zrealizowanych z udziałem kadry akademickiej.

Uniwersytet Jagielloński korzysta z doświadczeń innych ośrodków akademickich, także zagranicznych, współpracując z następującymi, zachodnioeuropejskimi szkołami wyższymi: 1) Uniwersytetem w Aarchus (Århus) w Danii w zakresie dostępności uczelni dla wszystkich, także dla niepełnosprawnych, 2) Uniwersytetem w Cambridge w Wielkiej Brytanii między innymi w zakresie podnoszenia świadomości kadry akademickiej w relacji: mistrz-uczeń, nauczyciel-student w kontekście niepełnosprawności, 3) Uniwersytetem w Edynburgu w Wielkiej Brytanii, 4) Uniwersytetem Islandzkim w Reykjaviku.

16 maja 2008 roku w ramach projektu DARE do Uniwersytetu Jagiellońskiego przyjechał prof. Willy Aastrup, filozof i wykwalifikowany psychoterapeuta duńskiego Uniwersytetu w Aarchus (Århus), aby prowadzić warsztaty dotyczące pogłębiania wiedzy oraz umiejętności $\mathrm{w}$ pracy ze studentami posiadającymi różnego rodzaju niepełnosprawności. Ponadto w tym dniu swoje spotkania odbyli w Biurze ds. Osób Niepełnosprawnych UJ: Liz Taylor z The Banger University w Wielkiej Brytanii (warsztaty dotyczące studentów z dysleksją, która jest traktowana na Wyspach Brytyjskich jako niepełnosprawność), Klitos Symeonides z Cypros Adult Education Association (Cypr), Bernard Queen z Learning Differences Ltd. To tylko jeden przykład wybrany spośród dziesiątek spotkań, konferencji, warsztatów, które odbyły się w minionych latach w UJ w związku z niepełnosprawnymi.

Wspomniane Biuro ds. Osób Niepełnosprawnych UJ wspólnie z jednostkami Uniwersytetu ma za zadanie stworzyć tak zwane „pakiety szkoleniowe” w celu podnoszenia wiedzy i umiejętności kadry nauczającej. Podjęto także współpracę z Uniwersytetem w Edynburgu (Szkocja, Wielka Brytania) w sprawie standardów wsparcia edukacyjnego. Mowa między innymi o transferze innowacji z Wielkiej Brytanii: Brytyjczycy mają tak zwany The Disability Discrimination Act z 1995 roku, czyli ustawę antydyskryminacyjną, której implikacje w sektorze edukacji są dość szczególne, czasem kontrowersyjne lub przynajmniej dyskusyjne, stąd należy uważać przy „mechanicznym” przenoszeniu wzorców brytyjskich do Polski. Nadto Biuro nawiązało kontakt z The University of Iceland w Reykjaviku w związku z osobami niepełnosprawnymi.

Biuro ds. Osób Niepełnosprawnych UJ przyjmuje cele i następującą definicję niepełnosprawności (zredagowaną w tak zwanej Konwencji Praw Osób Niepetnosprawnych z 13 grudnia 2006 roku: „Celem niniejszej konwencji jest popieranie, ochrona i zapewnienie pełnego i równego korzystania ze wszystkich praw człowieka i podstawowych wolności przez wszystkie osoby niepełnosprawne oraz popieranie poszanowania ich przyrodzonej godności. Do osób niepełnosprawnych zalicza się te osoby, które mają długotrwale naruszoną sprawność fizyczną, umysłową, intelektualną lub w zakresie zmysłów co może, w oddziaływaniu z różnymi barierami, utrudniać im pełny i skuteczny udział w życiu społecznym, na zasadzie 
równości z innymi osobami”»o. Model interaktywny zakłada istnienie oczywistej różnicy pomiędzy pełnosprawnością a niepełnosprawnością, trzeba ją znać, aby móc postępować adekwatnie do rzeczywistości.

\section{Aktywizacja skolaryzacyjna i zawodowa dotycząca osób niepełnosprawnych}

Nie ulega wątpliwości, że aktywizacja osób niepełnosprawnych i zachęcenie ich do podjęcia studiów wyższych, jeśli są one na tyle zdolne intelektualnie, że potrafią podołać wymogom programowym, stawianym studentom na danym kierunku studiów, jest pożyteczna i ze wszech miar potrzebna w każdej sytuacji, w każdym czasie. Trzeba wskazać między innymi na dwa cele studiów wyższych, akcentowane w pedagogice: 1) własny rozwój (własnej osobowości), 2) zdobycie konkretnego wykształcenia (dyplomu uprawniającego do uprawiania zawodu i do zajęcia pewnego miejsca w „drabinie społecznej”) ${ }^{11}$. Niepełnosprawni zatem, podobnie jak inni ludzie, mają dwa główne motywy podejmowania studiów wyższych: 1) własny rozwój intelektualny oraz kulturowy, 2) zdobycie konkretnego zawodu. Trzy elementy dydaktyczno-wychowawcze istotne są w procesie kształcenia w uniwersytecie: 1) wiedza teoretyczna, 2) umiejętności praktyczne i 3) postawa (kompetencje społeczne). Te trzy obszary dotyczą także studentów-osób niepełnosprawnych.

Aktywizacja zawodowa osób niepełnosprawnych w Polsce jest potrzebna zwłaszcza w perspektywie sytuacji załamania się systemu emerytalnego i rentowego w Polsce wskutek realnej katastrofy demograficznej. Bycie niepełnosprawnym nie oznacza wszak „wyroku skazującego”, ale często utrudnia podejmowanie pewnych czynności zawodowych w pełnym wymiarze. Celem państwa polskiego jest w tym obszarze aktywizacja tej grupy osób niepełnosprawnych, która jest w stanie przezwyciężyć trudności i podjąć naukę, a następnie pracę, nawet w specjalnych warunkach lub w niepelnym wymiarze (zawsze „praca nad pracą” jest tu w sumie opłacalna).

Dotychczasowe doświadczenia negatywne rządów lewicowo-liberalnych ukazały jednak całkowite fiasko polityki państwa wobec zatrudnienia osób niepełnosprawnych w naszym kraju (na przykład stopniowe wycofywanie się państwa $\mathrm{z}$ dofinansowania stanowisk pracy dla osób niepełnosprawnych, masowa likwidacja zakładów pracy chronionej, nieskuteczność czysto propagandowych akcji

\footnotetext{
${ }^{10}$ Por. Konwencja o prawach osób niepetnosprawnych, sporządzona w Nowym Jorku dnia 13 grudnia 2006 r. Dz. U. z 25 października 2012, poz. 1169, art. 1). Polska ratyfikowała tę konwencję w 2012 r. por. Ustawa z dnia 15 czerwca 2012 r. o ratyfikacji Konwencji o prawach osób niepetnosprawnych, sporzqdzonej w Nowym Jorku dnia 13 grudnia 2006 r., Dz. U. z 2 sierpnia 2012 r., poz. 882.

${ }^{11}$ Zbyszko Melosik, „Edukacja a stratyfikacja społeczna”, w: Pedagogika, podręcznikakademicki, t. 2, red. Zbigniew Kwieciński, Bogusław Śliwerski (Warszawa: Państwowe Wydawnictwo Naukowe 2006), 328-366. Z. Melosik zaprezentował tu szereg kontrowersyjnych stanowisk, prezentowanych przez współczesnych pedagogów zachodnioeuropejskich czy amerykańskich w sporze o funkcje i cele studiów wyższych (w uniwersytetach).
} 
billboardowych (reklamowych) werbalnego wspierania osób niepełnosprawnych przy zatrudnieniu, co jest finansowane ze środków wspólnotowych i krajowych, ale $\mathrm{w}$ rezultacie prowadzi do wielkiego marnowania pieniędzy bez przynoszenia spodziewanych efektów ${ }^{12}$.

Państwo wspiera i nadal powinno wspierać aktywizację skolaryzacyjną oraz zawodową osób niepełnosprawnych, ułatwiać im podejmowanie studiów, co przyniesie pozytywne owoce dla całej społeczności. Koszty aktywizacji zwrócą się, kiedy dana, zdolna do nauki i zdobycia odpowiedniego zawodu, osoba niepełnosprawna podejmie pracę: zacznie zarabiać nie tylko na siebie, ale też na innych. Zanim jeszcze młody człowiek z danym rodzajem niepełnosprawności trafi na studia, trzeba go jednak do podjęcia studiów zachęcić, wspomóc, w rozmaity sposób uświadomić mu możliwości, przekonać o ułatwieniach.

Celem jest wypracowanie jednolitego systemu działania, który na skalę społeczną docierałby z informacją do niepełnosprawnych uczniów oraz studentów. Jednym z ogniw takiej informacji są Biura ds. Osób Niepełnosprawnych. Należy poprzez szerokie działania o charakterze „przesiewowym” wychwycić w skali kraju grupę uczniów zdolnych intelektualnie, choć niepełnosprawnych pod różnymi względami (przykładowo z deficytami sensorycznymi) i pokierować ich karierą (wesprzeć ich rozwój edukacyjny) tak, aby trafili albo do wyższych szkół zawodowych lub uniwersytetów, albo do szkół dających konkretny zawód (rzemiosło), a następnie na rynek pracy.

\section{Dwa modele niepełnosprawności - medyczny oraz interaktywny}

Dagmara Nowak-Adamczyk zwraca uwagę na dwa sposoby ujęcia niepełnosprawności i wyróżnia: 1) model medyczny, 2) model interaktywny. W pierwszym z nich niepelnosprawność jest „niedoborem”, brakiem, deficytem czy „anormalnością", stąd, zdaniem autorki, fakt bycia niepełnosprawnym jest „negatywny” (według mnie niekoniecznie tak jest, zaś niepełnosprawność przy medycznym podejściu lokuje się słusznie, realistycznie wdanej osobie, wjej organizmie czy psychice). W drugim, interaktywnym, niepełnosprawność to „różnica”, fakt sam w sobie „obojętny” (nie negatywny), przy czym niepełnosprawność „wywodzi się ze wzajemnego oddziaływania danej osoby i społeczeństwa”. Ten drugi „model” jest moim zdaniem błędnie zdefiniowany, bo podejście interaktywne do niepełnosprawności, zakładające aktywizację jako pomoc niesioną przez społeczność na rzecz osób z danym deficytem, nie dowodzi jednak, że geneza niepełnosprawności leży w interakcji danej osoby-inwalidy (ang. in-valide) ze

\footnotetext{
${ }^{12} \mathrm{~W}$ potocznym odbiorze wszelkie reklamy (także billboardy) są kojarzone negatywnie jako ingerencje intruzów w przestrzeń publiczną lub prywatną, służące indoktrynacji społeczności przemocą wizualną. Przeciętny człowiek ma dość reklam, osaczają go one zwłaszcza w mieście, ze wszystkich stron, czy chce tego, czy nie chce (a zwykle - nie chce), stąd bierze się, moim zdaniem, nieskuteczność tego typu masowych akcji.
} 
społeczeństwem i nie zaprzecza to realistycznemu podejściu „medycznemu”, które niepełnosprawność, kalectwo, inwalidztwo wywodzi adekwatnie do rzeczywistości ze wskazanego braku organicznego albo pozaorganicznego (psychicznego) ${ }^{13}$. Możliwe jest zatem podejście humanistyczno-medyczne do osoby niepełnosprawnej, uznające medycznie ujmowane, organiczne lub nieorganiczne przyczyny powstania niepełnosprawności (realna geneza deficytu, realna geneza braku), przy jednoczesnym pozytywnym, wspomagającym, rzetelnym, w pełni „ludzkim” podejściu do danej osoby niepełnosprawnej, przy uwzględnieniu oczywistych różnic, wynikających z faktu bycia inwalidą.

Przy usuwaniu problemów związanych z niepełnosprawnością, zdaniem D. Nowak-Adamczyk, w ramach podejścia pierwszego typu (medycznego) stosuje się leczenie danej osoby przez specjalistę lub dostosowuje się daną osobę do obowiązującej normy (czyni to także specjalista), trzeba dodać: o ile to możliwe. $W$ ramach podejścia interaktywnego usuwanie problemów związanych z niepełnosprawnością polega na „zmienianiu wzajemnego oddziaływania między daną osobą a społeczeństwem”, przy czym czynnikiem sprawczym owego usunięcia problemów jest „dana osoba [niepelnosprawna], jednostka lub instytucja występująca wjej [osoby niepelnosprawnej] imieniu lub inna osoba [pełnosprawna] mająca wpływ na relacje między osobą [niepełnosprawną] a społeczeństwem"14. Definicja ta jest rozbudowana, niedokładna, wymagająca uściślenia, przyjęta przez autorkę ad hoc. Należy także zapytać, co autorka rozumie przez „interaktywność”, dosłownie: „między-aktywność”, „między-czynność”: aktywność, czynność pomiędzy kim a kim?

Trzeba jednak dodać, że drugi typ podejścia (interaktywny), jakkolwiek byłby rozumiany, nie zaprzecza typowi pierwszemu, czyli „medycznemu”: nie wyklucza się leczenia czy rehabilitacji danej osoby, o ile to możliwe, a także udziału specjalisty (lekarza, rehabilitanta, psychologa-terapeuty) w czynności zachodzącej pomiędzy osobą niepełnosprawną a osobą pełnosprawną. Typ „medyczny” można przecież także nazwać „interaktywnym”, bo w jego ramach zachodzi aktywność, czynność, czyli interakcja pomiędzy osobami: specjalistą a osobą niepełnosprawną. Obydwa podejścia dadzą się zatem połączyć, bo podejście medyczne jest zawsze „interaktywne”, zawsze też potrzebne (wszak specjaliści są niezbędni), natomiast kwestia edukacji społeczności dla celów niesienia pomocy osobom niepelnosprawnym również jest wskazana. To w zasadzie nie jest niczym nowym, wszak już starożytni nakazywali nieść pomoc innym: wszelkim osobom cierpiącym, kalekim, niewidomym, chromym, chorym, o czym świadczy historia chrześcijaństwa.

Podejście medyczno-interaktywne, czyli humanistyczno-medyczne, w pełni „ludzkie” i „specjalistyczne” zarazem, jest możliwe, w ten sposób uzyska się maksymalny efekt, zjednoczenie wszystkich możliwych, specjalistycznych sił

${ }^{13}$ Wszak ktoś od urodzenia jest niewidomy lub niedowidzący nie przez to, że społeczeństwo, w wyniku interakcji, takim go uczyniło, lecz jest to skutkiem konkretnego deficytu organicznego jego narządu wzroku. Geneza niepełnosprawności leży w organizmie danej osoby niewidomej od urodzenia, a nie w społeczności grupie osób, która się z danym niewidomym styka, wchodząc z nim w interakcje.

${ }^{14}$ Nowak-Adamczyk, Rodzaje. 
wspomagających: lekarzy, rehabilitantów, pielęgniarek, psychologów-terapeutów, pedagogów, łącznie z aktywizacją społeczności.

\section{Niepełnosprawni a społeczność, państwo, kultura, cywilizacja}

Aktywizacja całej społeczności w danym środowisku lokalnym wymaga z kolei systematycznych, świadomych działań pedagogicznych na miejscu, ale także w polskich, publicznych środkach masowej komunikacji, które mają pozytywną misję społeczną do spełnienia, wpisaną w ich statut nadawców publicznych. Misja wobec osób niepełnosprawnych nie kończy się na udziale tłumacza języka migowego dla głuchoniemych (głuchych) w programach telewizji publicznej, ale obejmuje także kształtowanie pozytywnych postaw u ogółu pełnosprawnych widzów czy słuchaczy w relacji do osób niepełnosprawnych. Chodzi o wychowanie obywateli do akceptacji wartości niepełnosprawności (inności, specyficzności potrzeb osób niepełnosprawnych), ale także o wzbudzenie u nich dobrej i wolnej woli niesienia osobistej pomocy niepełnosprawnym ludziom potrzebującym, w każdej sytuacji życiowej, w której się znajdują, w myśl zasady miłości bliźniego niezależnie od narodowości, rasy, płci, stanu, religii, wykształcenia, posiadanego majątku, przekonań politycznych $\mathrm{i}$ innych.

W szkole wyższej zakłada się w zasadzie sytuację modelową, w której nauczyciel akademicki jest osobą pełnosprawną (wzrokowo, słuchowo, psychicznie i ruchowo), natomiast student posiada deficyt $w$ jednej lub kilku sferach sprawności. Nie bierze się natomiast pod uwagę sytuacji odwrotnej: że nauczyciel akademicki także może być osobą niepełnosprawną (niedowidzi, niedosłyszy, ma trudność w poruszaniu się lub posiada jakieś deficyty psychiczne, ujawniające się na przykład lęki czy fobie). Dany deficyt nie przeszkadza jednak w uprawianiu zawodu, czego przykładem jest postać zmarłego przed laty znanego profesora filologii łacińskiej prof. Mariana Plezi (UJ), który, mimo niepełnosprawności wzroku (jednooczność) stał się naukowcem klasy światowej, tworząc dwa duże, wielotomowe słowniki lacińsko-polskie oraz mając liczący się dorobek naukowy i dydaktyczny. Nie korzystał przy tym z pomocy specjalistycznych serwisów informatycznych, bo takowych wtedy nie było.

Przykłady osób niepełnosprawnych pełnych heroizmu i wytrwałości, wybitnych naukowców-dydaktyków, można mnożyć, a także szczegółowo analizować w ramach historii nauki, jest to jednak osobny problem, na który zbyt mało dotąd zwracano uwagę, choć wart jest odrębnego potraktowania. Chodzi tu o przykład konkretny, że osoba niepełnosprawna może dojść do najwyższego szczebla kariery uniwersyteckiej, zostać dzięki własnej, heroicznej pracy profesorem, przydatnym dla państwa, uczącym innych. Ci nauczyciele akademiccy, mistrzowie heroizmu, żyją wśród nas, pracują, nawet często o tym nie wiemy, a studenci nie zdają sobie sprawy, ile wysiłku musi włożyć ich mistrz, aby pokonać własne niedomaganie fizyczne czy psychiczne, aby móc funkcjonować jako pełnoprawny, naukowo twórczy członek społeczności akademickiej. Dyskretna historia niepetnosprawnych uniwersytetów 
- taki przewrotny i paradoksalny tytuł mogłaby nosić książka traktująca o rzeszach osób niepełnosprawnych wykładających na uczelniach, a ukrywających swoje kalectwo w obawie przed reakcją społeczną ${ }^{15}$.

Jako ludzie cywilizacji zachodnioeuropejskiej, czyli łacińskiej, która była i jest cywilizacją chrześcijańską, kierujemy się zasadą dobra wspólnego (zasadę tę uwzględnia Konstytucja $\mathrm{RP}^{16}$ ), a do niego należy zaliczyć grupę osób niepełnosprawnych, którym możemy pomagać i przez to doskonalić siebie wewnętrznie w relacji do drugiego człowieka wymagającego pomocy, zrozumienia, życzliwości. Osoba niepełnosprawna jest wszak człowiekiem w pełni ${ }^{17}$, osobową jednością integralną, człowiekiem w każdym aspekcie: duchowym, psychicznym i cielesnym, mimo rozmaitych deficytów natury organicznej lub nieorganicznej, które ją dotknęły.

Nie możemy popełniać błędu antropologicznego ${ }^{18}$, błędu redukcjonizmu, który stał między innymi u podstaw niemieckiego totalitaryzmu: to narodowo-socjalistyczni ideolodzy III Rzeszy Niemieckiej (1933-1945) twierdzili, że osoba niepełnosprawna jest „niepełnowartościowym życiem”, co skutkowało ludobójstwem. Cywilizacja łacińska, chrześcijańska oparta jest na idei dobra wspólnego. Wartości moralne wspólne wszystkim ludziom ${ }^{19}$ nakazują czynić dobro drugiemu, a nie wyrządzać mu zła, co w szczególności obowiązuje każdego człowieka, zwłaszcza cywilizowanego, w relacji do osób niepełnosprawnych.

Konstytucja Rzeczypospolitej Polskiej z 2 kwietnia 1997 roku wskazuje na szczególną, ochronną i pomocniczą funkcję państwa w odniesieniu do niepełnosprawnych $^{20}$. Nie ogranicza ona pomocniczości państwa tylko do pewnego zakresu pomocy i nie stawia jej granic. Czy czyni tak, ponieważ celem jest człowiek jako najwyższe dobro (człowiek jako „dobro właściwe”, bonum honestum) ${ }^{21}$ ? Niepodległe

\footnotetext{
${ }^{15}$ Istnieje obecnie co prawda rejestr osób niepełnosprawnych i zgodnie z prawem, osoba niepełnosprawna z tak zwaną I lub II grupą inwalidzką (znaczny lub umiarkowany stopień niepełnosprawności) ma prawo do skróconego czasu pracy, ale przecież nauczyciele akademiccy pracują w ramach rocznego pensum zajęć. I co tu skracać w takim przypadku? Czy tylko prawo?

${ }^{16}$ Konstytucja Rzeczypospolitej Polskiej z dnia 2 kwietnia 1997 r., Dz. U. z 1997 r., nr 78, poz. 483, art. 82: „Obowiązkiem obywatela polskiego jest wierność Rzeczypospolitej oraz troska o dobro wspólne”. Por. także: Mieczysław A. Krąpiec, „Dobro wspólne”, w: Powszechna Encyklopedia Filozofii, t. 2 (Lublin: Polskie Towarzystwo Tomasza z Akwinu 2001), 628-639.

${ }^{17}$ Por. Dusza. Umyst. Ciało. Spór ojedność bytowa człowieka, red. naukowa Andrzej Maryniarczyk SDB, Katarzyna Stępień (Lublin: Polskie Towarzystwo Tomasza z Akwinu 2007).

18 Por. Błąd antropologiczny, red. naukowa Andrzej Maryniarczyk SDB, Katarzyna Stępień (Lublin: Polskie Towarzystwo Tomasza z Akwinu 2003).

${ }^{19}$ Por. Siły moralne wspólne wszystkim ludziom, ich źródła i rozwój poprzez wychowanie. Praca zbiorowa, (Bydgoszcz: Komitet Organizacyjny VI-tego Międzynarodowego Kongresu Wychowania Moralnego, 1934).

${ }^{20}$ Por. np. Konstytucja Rzeczypospolitej Polskiej z dnia 2 kwietnia 1997 r., Dz. U. z 1997 r., nr 78, poz. 483, art. 19, art. 67, ust. 1; art. 68, ust. 3; art. 69.

${ }^{21}$ Por. Andrzej Maryniarczyk, „Dobro”, w: Powszechna Encyklopedia Filozofii, t. 2, (Lublin: Polskie Towarzystwo Tomasza z Akwinu 2001), 620.
} 
państwo polskie jest jednak tylko narzędziem, środkiem w ręku suwerena-narodu ${ }^{22}$. Jak realizuje pomoc i ochronę niepełnosprawnych? W gruncie rzeczy to my sami, Polacy, sprawujemy ową szczególną opiekę, dajemy ową szczególną pomoc naszym niepełnosprawnym współobywatelom, bo „Rzeczpospolita Polska jest dobrem wspólnym wszystkich obywateli”23. To nie „oni” (wyalienowany aparat państwa), lecz „my” sami, jako ludzie obdarzeni sumieniem, jesteśmy w powinności pomagać osobom niepełnosprawnym, opiekować się nimi, bo jako obywatele (pełnosprawni i niepełnosprawni) tworzymy owo dobro wspólne zwane Rzeczpospolitą Polską.

Zasada pomocniczości państwa względem niepełnosprawnych współobywateli, także wobec uczniów czy studentów niepełnosprawnych, wzmacnia podejście integralne całej społeczności do nich. Obowiązuje przeto każdego, nikt nie może uchylić się od pomocy osobie niepelnosprawnej, udzielanej na miarę swoich możliwości. Podejście integralne do człowieka wynika z sumienia moralnego, a nie $\mathrm{z}$ prawa. $\mathrm{W}$ demokratycznym państwie głos obywateli ${ }^{24} \mathrm{w}$ wyborach czy referendach powinien przesądzać także o generalnym podejściu do niepełnosprawnych, wyznaczać generalne kierunki działania.

Niezależnie od ewentualnej ułomności prawa (także ułomnej Konstytucji III RP) nikt nie zwolnił obywateli z moralnego obowiązku pomocy bliźniemu, także temu niepełnosprawnemu, bo prawo stanowione nie ma władzy nad moralnością naturalną, wynikającą z natury ludzkiej, a nie z umowy społecznej (stanowionej ad hoc). Moralności (sumienia) nie da się „zawiesić” prawem stanowionym, bo jest ono odzwierciedleniem moralności („sumienności”), a nie na odwrót. Inną kwestią jest sytuacja, w której normy prawne traktowane są w odbiorze potocznym jako normy moralne ${ }^{25}$, choć jest to błędem logicznym.

\section{Wsparcie edukacyjne osób niepełnosprawnych na studiach}

Jest rzeczą czywistą, że osoby niepełnosprawne, wymagają wsparcia w pewnym zakresie. D. Nowak-Adamczyk w materiałach seminaryjnych przyjęła definicję autorstwa M. Perdeus-Białek: wsparcie edukacyjne to „szereg zabiegów umożliwiających osobie $\mathrm{z}$ daną niepełnosprawnością pełny dostęp do edukacji, zgodnie z zasadą tzw. równych praw i obowiązków. Oznacza to efektywne i racjonalne dostosowanie przestrzeni edukacyjnej tak, by studentów niepełnosprawnych traktować tak samo jak studentów bez niepełnosprawności” ${ }^{26}$. W tak zdefiniowanym podejściu kryje się jednak pułapka braku różnicy, czyli sztucznego jej zatarcia, a przecież wynika ona z obecności deficytów. Różnice między pełnosprawnym i niepełnosprawnym były, są i będą, o tym należy pamiętać, także wdziedzinie

\footnotetext{
${ }^{22}$ Konstytucja Rzeczypospolitej Polskiej z dnia 2 kwietnia 1997 r., Dz. U. z 1997 r., nr 78, poz. 483, preambuła, zdanie pierwsze.

${ }^{23}$ Konstytucja Rzeczypospolitej Polskiej z dnia 2 kwietnia 1997 r., Dz. U. z 1997 r., nr 78, poz. 483, art. 1.

${ }^{24}$ Konstytucja Rzeczypospolitej Polskiej z dnia 2 kwietnia 1997 r., Dz. U. z 1997 r., nr 78, poz. 483, art. 2 i 4.

25 Por. Wychowanie na rozdrożu. Personalistyczna filozofia wychowania, red. Franciszek Adamski (Kraków: Wydawnictwo Uniwersytetu Jagiellońskiego 1999).

${ }^{26}$ Nowak-Adamczyk, Rodzaje.
} 
edukacji. Nauczyciel powinien dostosować swoje postępowanie do specyfiki danego deficytu. Jakkolwiek słuszne jest podejście równościowe, to ludzie są równi z natury, a nie z postanowienia takiej czy innej władzy (nie w wyniku jakiejkolwiek umowy społecznej). Prawo naturalne stanowi o równości wszystkich ludzi w ich godności, wolności, w ich prawie do życia.

Konstytucja jako akt prawa stanowionego, będącego rodzajem umowy społecznej, tylko owo prawo naturalne wprowadza do świadomości społecznej, ale prawa naturalnego (prawa przyrodzonego człowiekowi) sama z siebie nie ustanawia. Konstytucja III RP tylko stwierdza sytuację zastaną (obecność naturalnego prawa moralnego w człowieku): „Przyrodzona i niezbywalna godność człowieka stanowi źródło wolności i praw człowieka i obywatela. Jest ona nienaruszalna, a jej poszanowanie i ochrona jest obowiązkiem władz publicznych" ${ }^{27}$. Zatem przyrodzona godność przynależy z natury każdemu człowiekowi, także niepełnosprawnemu. Państwo (władza publiczna) chroni godność osób niepełnosprawnych w każdej sytuacji, na każdym etapie edukacji, również w szkołach wyższych. Wszelkie usprawnienia w procesie dydaktycznym mają służyć zachowaniu tej przyrodzonej godności ludzkiej. Dotyczy to także usprawnień wdydaktyce akademickiej, skierowanych do niepełnosprawnych studentów.

Konstytucja RP stanowi, z woli wszystkich obywateli polskich, że: „Każdemu zapewnia się wolność wyboru i wykonywania zawodu oraz wyboru miejsca pracy. Wyjątki określa ustawa" ${ }^{28}$. Z zapisu konstytucyjnego wynika, że także każda osoba niepełnosprawna, o ile nie jest to zawarowane ustawą na zasadzie wyjątku, ma prawo do wolnego wyboru kierunku studiów i posiada wolność wyboru wykonywanego zawodu. Szkoły wyższe nie mogą zatem ni e przyjmować na studia osób niepełnosprawnych, o ile takowe osoby w sensie posiadanej wiedzy spełniają kryteria przyjęcia, chyba że zabrania tego ustawa. Każda osoba niepełnosprawna, zdolna intelektualnie, aby sprostać wymogom przyjęcia na studia, powinna być przyjęta na wybrane przez siebie w sposób wolny studia. Podobnie rzecz się ma z wolnością wykonywania zawodu przez osoby niepełnosprawne po studiach wyższych. Niepełnosprawni z dyplomem uczelni mają prawo do wykonywania wybranego zawodu, chyba że zabrania tego ustawa. Jest rzeczą oczywistą, że nie może być pielęgniarką osoba całkowicie niewidoma, ale może ona pracować jako psycholog kliniczny i rozmawiać z pacjentami, prowadzić psychoterapię, ćwiczenia relaksacyjne lub zajęcia z innymi niewidomymi, którzy wszak mają trudność w rozumieniu kultury wizualnej.

Proces edukacyjny wymaga dostosowania uczelni do potrzeb osób niepełnosprawnych. Nie da się jednak nigdy całkowicie zrekompensować wszystkich deficytów każdego studenta niepełnosprawnego. Można się tylko do owego niedościgłego wzorca zbliżyć. O ile istnieje prosta możliwość niwelacji barier architektonicznych w nowo budowanych kampusach uczelnianych - pojawiają się:

\footnotetext{
${ }^{27}$ Konstytucja Rzeczypospolitej Polskiej z dnia 2 kwietnia 1997 r., Dz. U. z 1997 r., nr 78, poz. 483, art. 30.

${ }^{28}$ Konstytucja Rzeczypospolitej Polskiej z dnia 2 kwietnia 1997 r., Dz. U. z 1997 r., nr 78, poz. 483, art. 65, ust. 1.
} 
szerokie windy czy drzwi mieszczące wózki inwalidzkie, automatyczne podnośniki, pochylnie, równie pochyłe-podjazdy i inne, o tyle w wielu przypadkach owo wsparcie w przestrzeni edukacyjnej napotyka trudności. Nie chodzi tu tylko o przestrzeń traktowaną dosłownie, ale także o sferę osobową, mentalną, świadomościową29.

Mowa o przezwyciężeniu mentalności ludzkiej, która jest trudna do zmiany, zwłaszcza $\mathrm{u}$ osób o utrwalonych nieodpowiednich schematach poznawczych, wyniesionych ze szkół lub z domu albo z kontaktów z grupami nieformalnymi (na przykład rówieśniczymi). Plastyczność psychiki dorosłych ulega usztywnieniu, trudno ją zmienić, trzeba zatem profilaktycznie i systematycznie uczyć dzieci od najmłodszych lat, że „inwalida” to także człowiek, wymagający pewnej pomocy w sytuacji, w której się znajduje. Kultura osobista wymaga elementarnego szacunku dla drugiego, zwłaszcza niepelnosprawnego. Kiedy owe dzieci dorosną, kiedy staną się studentami, nauczycielami, menadżerami, lekarzami, łatwiej im będzie pomagać innym (również niepełnosprawnych), bo będą bardziej rozumieć ich potrzeby. „Spotkanie z innym”, „spotkanie innego” jest okazją do nauczenia się czegoś dobrego. Altruizm i miłość bliźniego są zawsze cechami moralnie pozytywnymi. Miłość została adekwatnie do rzeczywistości zdefiniowana w personalistycznym realizmie (filozofii klasycznej) jako „roztropna troska o dobro innych”. Miłość do osób niepełnosprawnych jest więc roztropną troską o ich rzeczywiste dobro.

Uniwersytet narodził się w cywilizacji łacińskiej jako instytucja założona przez chrześcijan, przez Kościół Katolicki w średniowieczu, dlatego w Polsce w wyższych uczelniach powinniśmy pamiętać o wzorcach chrześcijańskich, o pomocy bliźniemu w ramach kultury miłosierdzia; szczególnie bliźniemu, gdy jest osobą niepełnosprawną. Wsparcie edukacyjne osób niepełnosprawnych jest naszym obowiązkiem moralnym jako ludzi, a nie tylko jako chrześcijan. Tradycja roztropnego miłosierdzia zobowiązuje, a chrześcijaństwo niewątpliwie jest dobrą tradycją i wypracowało dobre wzorce postępowania, warte naśladowania, sprawdzone przez dwa tysiące lat w rozmaitych kulturach.

\section{Sumienie a niepełnosprawni w uniwersytecie}

Poza i ponad regulacjami prawnymi, obowiązującymi przepisami, regulaminami, statutami ważne jest prawidłowo ukształtowane sumienie człowieka. W chrześcijańskiej kulturze (ze stanowiska pedagogiki katolickiej) osoba prawidłowo uformowana pod względem moralnym wie, co jest dobre, a co jest złe, nie relatywizuje. Sumienie jest głosem wewnętrznym człowieka uważanym ponadto za głos Boga w duchowości ludzkiej.

Pełnosprawne sumienie (zdolne do rozróżniania dobra i zła) to przeciwieństwo sumienia niepełnosprawnego (niezdolnego do rozróżniania dobra od zła). Tę kwestię proponuję postawić jako punkt wyjścia. Niepełnosprawne sumienie jest sumieniem relatywizującym, zrelatywizowanym, nieprawidłowo uformowanym. Owa „niepełnosprawność” sumienia oznacza faktycznie nieprawidłowość wychowania

\footnotetext{
${ }^{29}$ Migas, Problemy.
} 
moralnego danego człowieka, a jego brak, przy jednoczesnej łatwo dosięgającej człowieka demoralizacji czy deprawacji, prowadzi do wypaczenia sumienia, do zatarcia w jego świadomości granicy pomiędzy dobrem a złem. W gruncie rzeczy mówimy o takim kimś, że jest człowiekiem „bez sumienia”.

Sumienie prawidłowo ukształtowane prowadzi do odpowiednich zachowań i właściwego postępowania względem drugiego człowieka: szanującego jego godność, nieinstrumentalizującego go ${ }^{30}$. Nauczyciel akademicki o prawidłowo uformowanym sumieniu szanuje zarówno godność i wolność innych ludzi, w tym studentów (również niepełnosprawnych), ale i swoją własną godność oraz wolność, wszak także jest człowiekiem. Pytanie o granice wolności i godności jest w tej sytuacji głęboko uzasadnione. Jak według prawidłowo uformowanego sumienia postępować, nie naruszając tych granic?

W relacji z człowiekiem niepełnosprawnym kwestie godności i wolności są niezwykle delikatne. Jeśli niektórzy studenci ich nadużywają, to co wtedy? Niektórzy wykładowcy uniwersyteccy takich roszczeniowych, agresywnych, atakujących słowem (a czasem i nie tylko), studentów zwą potocznie „hunwejbinami”. Jeśli owym nadużywającym wolności wobec innego człowieka jest osoba pełnosprawna - to jak postąpić? A jeśli ową osobą jest niepełnosprawny człowiek - czy należy postąpić inaczej, niż wobec osoby pełnosprawnej? Pytanie o granice wolności wobec innego wiąże się z pytaniem o sumienie. Jeśli granicą mojej wolności jest wolność innego człowieka, po Tischnerowsku mówiąc, to także należy przyjąć zasadę odwrotną: jeśli granicą cudzej wolności jest moja własna wolność, to ten inny człowiek także musi ustanowić granice swojej wolności w relacji ze mną. Nie mogę mu pozwolić na łamanie mojej wolności w imię jego wolności.

Z innej jeszcze strony patrząc: czy niepełnosprawny człowiek może w imię swojej wolności odmówić wykonania czegoś, o co prosi słusznie wykładowca? I czy wykładowca w takiej sytuacji może naruszyć wolność osoby niepełnosprawnej, aby uzyskać słuszną rzecz, realne dobro dla niej samej, dla osoby niepełnosprawnej? A czy studiujący niepełnosprawny powinien zawsze odmawiać wykonywania poleceń wykładowcy, jeśli zagrażałoby to jej zdrowiu (w jego własnym przekonaniu)? Jeśli student chory psychicznie ma poczucie klaustrofobii i pragnie zimą podczas mrozu, aby okno sali wykładowej było otwarte na oścież, bo wtedy ma poczucie bezpieczeństwa, to co ma zrobić wykładowca wimię wolności i praw osób niepełnosprawnych? Może otworzyć drzwi na korytarz i wykładać przy otwartych drzwiach? A jeśli to dezorganizuje zajęcia, bo jest gwar i obcy zaglądają raz po raz do sali, co powoduje dyskomfort pozostałych studentów? A jeśli nie otworzy okna lub drzwi, student niepełnosprawny może czuć się pokrzywdzony i poskarżyć się władzom uczelni na dyskryminację? Tego typu dylematy moralne wykładowca powinien indywidualnie rozstrzygnąc we własnym, prawidłowo uformowanym sumieniu.

${ }^{30}$ Instrumentalizacja człowieka może być dowolna albo mimowolna (jak uwaga): czasem świadomie człowiek drugiego traktuje jako środek do celu, a nie jako cel sam w sobie najwyższy (instrumentalizacja dowolna), a czasem robi to nieświadomie (instrumentalizacja mimowolna). 


\section{Podsumowanie}

Niniejszy tekst inspirowany jest tradycją realistyczną dominującą w nurcie pedagogiki i kultury chrześcijańskiej (szczególnie katolickiej) w Polsce. Realistyczna filozofia pomaga w głębszym rozumieniu natury człowieka, jego moralnych dylematów, konfliktów i klauzul sumienia, które umożliwiają zapobieżenie złu, albo przynajmniej nieprzykładanie ręki do złego czynu czy wypowiedzi (słowa). Na jaką klauzulę sumienia może powołać się wykładowca, nauczyciel akademicki? Czy wolno mu się wogóle powoływać na jakąkolwiek klauzulę, skoro jest rozliczany z zachowania prawa? Pytanie o granice stosowania klauzuli sumienia - to kwestia na osobne studia. Zagadnienia kształcenia studentów niepełnosprawnych w szkole wyższej (w uniwersytecie) z pewnością zawierają także komponentę etyki. Filozofia dobra jest tu podstawą czynów. W niniejszym przyczynku tylko zasygnalizowano problematykę i kwestie etyczne dotyczące osób niepełnosprawnych.

Streszczenie: 1. Celem artykułu jest pokazanie sytuacji osób niepełnosprawnych w uniwersytecie wXXI wieku na wybranych przykładach. 2. Metodologia. Autor posłużył się historiograficzną metodą analizy dokumentu oraz obserwacją. 3. Główne wyniki analizy. Autor ukazuje następujące problemy: niepełnosprawni a uniwersytet (kontekst mistrza), Uczelniane Biuro do spraw Osób Niepelnosprawnych, edukacyjną i zawodową aktywność osób niepelnosprawnych, dwa modele niepełnosprawności (medyczny oraz interaktywny). W artykule przedstawiono także problem niepełnosprawnych w kontekście kategorii takich jak społeczność, państwo, kultura, cywilizacja. Autor pokazuje kształtowanie u studentów postaw altruistycznych wobec osób niepełnosprawnych oraz wsparcie edukacyjne osób niepełnosprawnych na studiach. Artykuł porusza kwestię sytuacji niepełnosprawnych słuchowo w szkole wyższej (metodyka pracy z takimi studentami) oraz niewidomych w kontekście kultury wizualnej w uniwersytecie. Autor opisał pewne problemy sumienia i niepełnosprawnych w uniwersytecie. 4. Ograniczenia wyników analizy. Artykuł może być przyczynkiem do dyskusji nad miejscem osób niepełnosprawnych w uniwersytecie. Ograniczenia dotyczą odniesienia do uniwersytetu. 5. Implikacje praktyczne. Wyniki analiz można zastosować w dyskusji jako racjonalne argumenty na rzecz zmiany sytuacji osób niepełnosprawnych na uniwersytecie. 6. Implikacje społeczne. Wyniki analiz mogą odnosić się do grupy osób niepełnosprawnych studentów w uniwersytecie. 7. Oryginalność artykułu (nowa wartość, nowość). Artykuł pokazuje źródłowo i na przykładach sytuacje osób niepełnosprawnych $\mathrm{w}$ uniwersytecie w kontekście kulturowym oraz możliwości pomocy, wsparcia.

Słowa klucze: uniwersytet, niepełnosprawni, sumienie, głuchoniemi, personalizm, prawa człowieka, chrześcijaństwo, etyka, mistrz-uczeń, modele, altruizm, kultura, cywilizacja 


\section{Bibliografia}

Błąd antropologiczny, red. naukowa Andrzej Maryniarczyk SDB, Katarzyna Stępień. Lublin: Polskie Towarzystwo Tomasza z Akwinu, 2003.

Cwalina, Teresa. „Dotykanie niewidzialnego. Z doświadczeń tyflologa warteterapii”. W: Edukacja w arteterapii: Międzynarodowa Konferencja Szkoleniowo-Naukowa z cyklu „Psychiatria i Sztuka”, red. Grażyna Borowik, Andrzej Kowal, 41-49. Kraków: Wydz. Sztuki Uniwersytetu Pedagogicznego im. KEN, Fundacja Instytut Wydawniczy „MAXIMUM”, 2013.

Dusza. Umyst. Ciało. Spór ojedność bytową człowieka, red. nauk. Andrzej Maryniarczyk SDB, Katarzyna Stępień. Lublin: Polskie Towarzystwo Tomasza z Akwinu, 2007.

Edukacja osób niepetnosprawnych, red. Aleksander Hulek. Warszawa: Polska Fundacja Upowszechnienia Nauki, 1993.

Edukacja warteterapii: Międzynarodowa Konferencja Szkoleniowo-Naukowa zcyklu „Psychiatria i Sztuka"', red. Grażyna Borowik, Andrzej Kowal. Kraków: Wydział Sztuki Uniwersytetu Pedagogicznego im. Komisji Edukacji Narodowej, Fundacja Instytut Wydawniczy „MAXIMUM”, 2013.

Grzegorzewska, Maria. Psychologja niewidomych, t. 1. Warszawa, Lwów: Naukowe Towarzystwo Pedagogiczne, 1929.

Kijak, Remigiusz. „Stygmatyzacja społeczna czy akceptacja? Wyniki badań”. Niepetnosprawność i Rehabilitacja 1 (2007): 3-24.

Konstytucja Rzeczypospolitej Polskiej z dnia 2 kwietnia 1997 r., Dz. U. z 1997 r., nr 78, poz. 483.

Konwencja o prawach osób niepetnosprawnych, sporządzona w Nowym Jorku dnia 13 grudnia 2006 r. Dz.U. z 25 października 2012, poz. 1169.

Krąpiec, Mieczysław A. „Dobro wspólne”. W: Powszechna Encyklopedia Filozofii, t. 2, 628-639. Lublin: Polskie Towarzystwo Tomasza z Akwinu, 2001.

Maryniarczyk, Andrzej. „Dobro”. W: Powszechna Encyklopedia Filozofii, t. 2, 620-626, oraz bibliogr. Lublin: Polskie Towarzystwo Tomasza z Akwinu, 2001.

Melosik, Zbyszko. „Edukacja a stratyfikacja społeczna”. W: Pedagogika, podręcznik akademicki, t. 2, red. Zbigniew Kwieciński, Bogusław Śliwerski, 328-366. Warszawa: Państwowe Wydawnictwo Naukowe 2006.

Migas, Agata. „Problemy psychospołeczne osób zograniczoną sprawnością”. Niepetnosprawność i Rehabilitacja 4 (2008): 22-42.

Nowak-Adamczyk, Dagmara. Rodzaje wsparcia istrategie nauczania studentów nieshyszących i słaboshyszących $w$ kontekście kształcenia pedagogów, materiał multimedialny, plansz 43 [materiał pomocniczy Biura ds. Osób Niepełnosprawnych UJ na III Seminarium Dydaktyki Akademickiej Kraków 26-27 listopada 2007 r. w Instytucie Pedagogiki UJ].

Pedagogika kultury - wychowanie do wyboru wartości, red. Bogusław Żurakowski. Kraków: Oficyna Wydawnicza „Impuls”, 2003.

Sity moralne wspólne wszystkim ludziom, ich źródla irozwój poprzez wychowanie. Praca zbiorowa. Bydgoszcz: Komitet Organizacyjny VI-tego Międzynarodowego Kongresu Wychowania Moralnego, 1934.

Tytko, Mariusz M. „Kilka uwag o udziale ucznia niepełnosprawnego w kulturze”. Niepetnosprawność i Rehabilitacja 4 (2008): 67-72.

Ustawa zdnia 15 czerwca 2012 r. o ratyfikacji Konwencji o prawach osób niepelnosprawnych, sporządzonej w Nowym Jorku dnia 13 grudnia 2006 r., Dz. U. z 2 sierpnia 2012 r., poz. 882.

Wojciechowski, Franciszek. Dziecko niepetnosprawne w środowisku wiejskim. Rzeszów: WSP 1993. 
Wychowanie na rozdrożu. Personalistyczna filozofia wychowania, red. Franciszek Adamski. Kraków: Wydawnictwo UJ, 1999.

Żuraw, Hanna. Uczestnictwo kulturalne mtodzieży niepetnosprawnej. Warszawa: Wydawnictwo „Żak” 1996. www.http://bon.uj.edu.pl [dostęp: 22.10.2008].

www.http://bazy.ngo.pl/search/info.asp?id=76535 [dostęp: 22.10.2008]. 